\title{
Phytochemical and in vitro antisnake venom activity of the methanol leaf and stem bark extracts of Leptadenia hastata (Asclepiadaceae) against Naja nigricollis venom
}

\author{
L. G. Hassan ${ }^{1}$, A. J. Yusuf², N. Muhammad ${ }^{1}$, C. Ogbiko ${ }^{1 *}$, M. D. Mustapha ${ }^{1}$
}

\begin{abstract}
Snake envenomation is a major cause of death and morbidity in many developing countries. Leptadenia hastata (Pers.) Decne (Asclepiadaceae) has been reportedly used in traditional medicine as an antivenom, antiulcer, antidiabetic, analgesic, antibacterial, antiviral agent and cardiovascular disorders. This research design is to investigate the phytochemical analysis and phospholipase $A_{2}$ enzyme inhibition potential of $L$. hastata leaf and stem bark extracts using standard procedures. Preliminary phytochemical screening revealed the presence of key constituents such as carbohydrates, tannins, flavonoids, alkaloids, triterpenes, steroids, saponins, and diterpenes. The methanol leaf and stem extracts were able to inhibit the hydrolytic action of phospholipase $A_{2}$ enzyme in a concentration-dependent manner. The research findings lay credence to the folkloric claim of the leaf and stem of $L$. hastata as an anti-snake venom.
\end{abstract}

Keywords: Leptadenia hastata, Phytochemical, Naja nigricollis, Phospholipase $\mathrm{A}_{2}$

Asian Pac. J. Health Sci., (2020); DOI: 10.21276/apjhs.2020.7.3.3

\section{INTRODUCTION}

Natural products from medicinal plants, either as pure compounds or as standardized extracts, provide unlimited opportunities for new drug discoveries due to the unmatched availability of chemical diversity. ${ }^{[1]}$ It has been estimated that approximately over half of the pharmaceuticals in clinical use today are derived from natural products. ${ }^{[2]}$ Some natural product-derived drugs that are a hallmark of modern pharmaceutical care include quinine, theophylline, penicillin G, morphine, paclitaxel, digoxin, vincristine, doxorubicin, cyclosporine, and vitamin A among many other examples. ${ }^{[2]}$ For centuries, natural substances, particularly plants, have been used to control and treat diseases and this has culminated in the discovery of the majority of modern pharmaceutical agents..$^{[3]}$

Leptadenia hastata (Pers.) Decne a member of the Asclepiadaceae family are mostly herbs and shrubs with white sap comprising about 250 genera and 2,000 species, many of which are lianous and some cactus-like succulents with reduced leaves. ${ }^{[4]}$ L. hastata is referred locally in Nigeria as "yahdiya" in Hausa and as "hagalhadjai" in Arabic. The plant leaves are used traditionally in the management of various ailments such as onchocerciasis, ${ }^{[5]}$ scabies, ${ }^{[6]}$ hypertension, catarrh, skin diseases, wound healing, snakebite, and prostate complaint..$^{[7]}$

Snakebite is a major cause of morbidity and mortality in Nigeria, especially in rural areas, where large numbers of envenoming and deaths are yearly reported. Venom from snake bite is largely composed of many complex compounds such as proteins, enzymes, neurotoxins, coagulants, anticoagulants, and other substances with cytotoxic effects. The venom is water-soluble, has a specific gravity of 1.03 , and is acidic in nature. ${ }^{[8]}$ Phospholipase $A_{2}$ enzyme ( $\left.P L A_{2} E\right)$ is known to stimulate the phospholipid membrane releasing arachidonic acid causing inflammation and pain at the bite site. ${ }^{[9]}$ Snake venom is hemotoxic, mainly affecting the circulatory system and muscular system, causing excessive scarring, hemorrhagic, coagulant defects, hypovolemic shock, pyrogen reaction, and serum sickness. ${ }^{[10,11]}$ The immediate administration of antisnake venoms is the only current treatment for snake bite
'Department of Pure and Applied Chemistry, Usmanu Danfodiyo University, Sokoto, Nigeria

2Department of Pharmaceutical and Medicinal Chemistry, Usmanu Danfodiyo University, Sokoto, Nigeria

Corresponding Author: C. Ogbiko, Department of Pure and Applied Chemistry, Usmanu Danfodiyo University, Sokoto, Nigeria. Phone: +2348080398933. Email: cyril.ogbiko@udusok.edu.ng

How to cite this article: Hassan LG, Yusuf AJ, Muhammad N, Ogbiko C, Mustapha MD. Phytochemical and in vitro antisnake venom activity of the methanol leaf and stem bark extracts of Leptadenia hastata (Asclepiadaceae) against Naja nigricollis venom. Asian Pac. J. Health Sci., 2020; 7(3):11-13

Source of support: Nil

Conflict of interest: None

Received: 14/04/2020 Revised:05/06/2020 Accepted: 15/06/2020

victims which is accompanied by a number of side effects coupled with its unavailability and problem of storage conditions especially in the hot humid climate of Northern Nigeria thereby restricting its usage. The side effects of ASVs are largely due to the action of high concentrations of non-immunoglobulin proteins present in commercially available hyperimmune antivenom. ${ }^{[12,13]}$ Over the years, many attempts have been made for the development of snake venom antagonists, especially from plants sources; $;^{[14]}$ hence, this study explores the phospholipase $A_{2}$ inhibition potential of $L$. hastata leaf and stem bark against Naja nigricollis venom [Figure 1].

\section{Materials and Methods}

\section{Collection and Identification of Plant Materials}

The leaves and stem of L. hastata were collected in July 2019 from Dange town, Dange Shuni local government area of Sokoto State, Nigeria. They were authenticated at the herbarium unit, Department of Pharmacognosy and Ethnomedicine, Usmanu 
Danfodiyo University Sokoto, Nigeria, where herbarium specimen were deposited and voucher number PCG/UDUS/894 was issued. The samples were shade dried at room temperature for 10 days, reduced to a fine powder using mortar and pestle, labeled and stored in an airtight glass container until ready for use.

\section{Extraction of Plant Materials}

The powdered leaves $(84.23 \mathrm{~g})$ and stem $(64.42 \mathrm{~g})$ of $L$. hastata were cold macerated using absolute methanol for $48 \mathrm{~h}$. The extracts were concentrated using a rotary evaporator at $40^{\circ} \mathrm{C}$ at reduced pressure. The residues referred to as the methanol leaf and stem extracts were obtained and coded MEL and MES, respectively.

\section{Preliminary Phytochemical Screening}

Chemical tests were carried out on the MEL and MES extracts to identify the presence of various phytoconstituents such as alkaloids, flavonoids, and tannins, among others using standard procedures. ${ }^{[15-18]}$

\section{Snake Venom Sample}

The venom sample of Naja nigricollis with an $\mathrm{LD}_{99}$ value of $5.75 \mathrm{mg} / \mathrm{kg}$ was obtained from Dr. Amina Yusuf Jega of the Department of Pharmaceutical and Medicinal Chemistry, Faculty of Pharmaceutical Sciences, Usmanu Danfodiyo University Sokoto. It was preserved in a desiccator at $8^{\circ} \mathrm{C}$ until ready for use.

Table 1: Extraction yield of the plant extracts

\begin{tabular}{lcccc}
\hline Part used & $\begin{array}{c}\text { Quantity } \\
\text { macerated }(\mathrm{g})\end{array}$ & $\begin{array}{c}\text { Volume of } \\
\text { methanol } \\
\text { used }(\mathrm{mL})\end{array}$ & $\begin{array}{c}\text { Weight of } \\
\text { obtained } \\
\text { extract }(\mathrm{g})\end{array}$ & \% yield \\
\hline Leaves & 84.23 & 750 & 16.10 & 19.12 \\
Stem & 64.20 & 750 & 21.05 & 32.80 \\
\hline
\end{tabular}

\section{Phospholipase $\mathrm{A}_{2}$ Assay}

Acidimetric assay for $\mathrm{PLA}_{2}$, as described by Tan and Tan, ${ }^{[19]}$ was adopted. Constant volumes of a substrate comprising calcium chloride $(18 \mathrm{mM})$, sodium deoxycholate $(8.1 \mathrm{mM})$, and egg yolk were mixed and stirred for $10 \mathrm{~min}$ to produce a homogeneous egg yolk suspension. Using $1 \mathrm{M}$ sodium hydroxide solution, the $\mathrm{pH}$ of the suspension was adjusted to $8.0 .0 .1 \mathrm{~mL}$ of the snake venom (0.1- $0.5 \mathrm{mg} / \mathrm{mL}$ ) was added each to $15 \mathrm{~mL}$ to initiate the process of hydrolysis. About $0.9 \%$ normal saline was used as the negative control. The $\mathrm{pH}$ of the suspension was observed after 2 min using a pH meter. While a 1.0 unit pH decline corresponds to $133 \mu \mathrm{mol}$ fatty acids released in the egg yolk mixture, the enzymatic activity of PLA ${ }_{2}$ was recorded in micromoles of fatty acids released/minute.

To test, the anti-snake venom potential of $L$. hastata. $0.1 \mathrm{mg}$ of the snake venom was pre-incubated with $0.1-0.6 \mathrm{mg} / \mathrm{mL}$ concentration of the extracts to neutralize the hydrolytic action of $\mathrm{PLA}_{2}$. The protection offered by the extracts that were calculated and represented in terms of percentage using the following expressions:

$$
\text { Enzyme activity }=\frac{\mu \mathrm{mol} \text { of fatty acid released }}{\text { Time taken in minute }}
$$

$$
\% \text { Enzyme activity }=\frac{\begin{array}{l}
\text { Enzyme activity } \\
\text { of the test sample }
\end{array}}{\begin{array}{l}
\text { Enzyme activity } \\
\text { of the control }
\end{array}} \times 100
$$$$
\% \text { Enzyme inhibition = 100-Enzyme activity }
$$

\section{Results and Discussion}

\section{Percentage Yield}

\begin{tabular}{|c|c|c|c|c|}
\hline Phytoconstituents & Test & Observation & Inference (MEL) & Inference (MES) \\
\hline \multirow[t]{2}{*}{ Carbohydrates } & Molisch & Red precipitate & + & + \\
\hline & Fehling's & Red precipitate & + & + \\
\hline Tannins & Ferric chloride & Precipitate & + & + \\
\hline Flavonoids & Alkaline test & Orange color & + & + \\
\hline \multirow[t]{2}{*}{ Alkaloids } & Wagner's & Cream-colored precipitate & + & + \\
\hline & Mayer's & Reddish-brown absent & + & + \\
\hline Triterpenes/Steroids & Salkowski's & Yellow color & - & + \\
\hline Saponin & Frothing & Persisting froth & + & + \\
\hline Diterpenes & Copper acetate & Emerald green color & + & + \\
\hline
\end{tabular}

The result of the extraction yield of the leaves and stem bark of $L$. hastata with respect to the quantity macerated is presented in Table 1.

Table 2: Preliminary phytochemical screening of $L$. hastata MEL and MES extracts

\begin{tabular}{|c|c|c|c|c|c|c|c|}
\hline Samples & Conc. $(\mathrm{mg} / \mathrm{mL})$ & $\Delta T$ & $\Delta p H$ & $\begin{array}{c}\text { Fatty acid released } \\
(\mu \mathrm{mol})\end{array}$ & $\begin{array}{l}\text { Enzyme activity } \\
(\mu \mathrm{mol} / \mathrm{FA} / \mathrm{min})\end{array}$ & $\begin{array}{c}\text { Enzyme } \\
\text { activity (\%) }\end{array}$ & $\begin{array}{c}\text { Enzyme } \\
\text { inhibition (\%) }\end{array}$ \\
\hline MES & 0.6 & 15 & 0.41 & 54.53 & 3.64 & 49 & 51 \\
\hline MES & 0.3 & 16 & 0.46 & 61.18 & 3.82 & 50 & 50 \\
\hline MES & 0.1 & 17 & 0.50 & 66.50 & 3.91 & 52 & 48 \\
\hline MEL & 0.6 & 18 & 0.48 & 63.84 & 3.54 & 47 & 53 \\
\hline MEL & 0.3 & 19 & 0.53 & 70.49 & 3.71 & 49 & 51 \\
\hline MEL & 0.1 & 20 & 0.59 & 78.47 & 3.92 & 52 & 48 \\
\hline VENOM & 0.1 & 15 & 0.85 & 113.05 & 7.53 & 100 & 0 \\
\hline VENOM & 0.3 & 16 & 0.92 & 122.36 & 7.64 & 100 & 0 \\
\hline VENOM & 0.5 & 17 & 0.98 & 130.34 & 7.66 & 100 & 0 \\
\hline ASV & - & & & & 0.93 & 27.1 & 72.1 \\
\hline
\end{tabular}

+: Presence, -: Absence of phytochemical, MEL: Methanol leaf extract, MES: Methanol stem extract

Table 3: Phospholipase $\mathrm{A}_{2}$ activity of MEL and MES extracts of Leptadenia hastate

MEL: Methanol leaf extract, MES: Methanol stem extract, ASV: Standard antivenom, $\Delta \mathrm{T}$ : Change in time, $\Delta \mathrm{pH}: \mathrm{Change}$ in $\mathrm{pH}$ 


\section{Phytochemical Screening}

Preliminary phytochemical screening of the MEL and MES of $L$. hastata showed the presence of important secondary metabolites (Table 2).

Polyphenols were the major secondary metabolites found in the extracts which could be attributed to the antisnake venom activity of the plant. Thus, studies have shown that polyphenols possess protein - binding and enzyme inhibiting properties, which could invariably inhibit snake venom PLA activities, an enzyme presents in cobra venom. ${ }^{[20]}$

\section{Phospholipase $A_{2}$ Assay}

The result of the phospholipase $A_{2}$ inhibition of the snake venom when challenged with the MEL and MES extracts of L. hastata is presented in Table 3.

$\mathrm{PLA}_{2}$ assay is an important assay mainly used to test for the anti-snake venom of plant extracts. In this assay, the enzyme was hydrolysed and free fatty acids were released in the presence of sodium deoxycholate. $N$. nigricollis venom was found to liberate fatty acids, which was measured in terms of a decrease in $\mathrm{pH}$ of egg yolk suspension. MES inhibited the hydrolytic action of $\mathrm{PLA}_{2}$ enzyme in a concentration-dependent manner with 48, 50 , and $51 \%$ inhibition at $0.1,0.3$, and $0.6 \mathrm{mg} / \mathrm{mL}$, while MEL had an inhibition of 48,51 , and $53 \%$ at $0.1,0.3$, and $0.6 \mathrm{mg} / \mathrm{mL}$. Comparably, MEL had better antisnake venom effect than MES at the highest concentration. These results significantly blocked many of the toxic effects of $N$. nigricollis venom in vitro. Which could possibly be due to the extracts acting through a mechanistic intervention rather than a direct physical interaction with the venom in vitro as this is similar to the mode of action of many polyphenolic compounds found in plant extracts. ${ }^{[21]}$

This result is in agreement with the report of Ode and Asuzu ${ }^{[22]}$ who used different venom concentrations different from that reported with the results following the same trend, although snake venom neurotoxin content varies both qualitative and quantitative from region to region within the same species. ${ }^{[23,24]}$ Further, research is currently being advanced in the fractionation assay of the L. hastata extract to identify the component(s) responsible for the inhibitory effect reported.

\section{Conclusion}

The present findings validated the ethnomedicinal claim of the use of $L$. hastata as an antisnake venom, particularly N. nigricollis venom. The plant extracts were significantly effective in neutralizing the main toxic and enzymatic effects of $N$. nigricollis venom. The antivenom properties of both plant extracts were potent enough to neutralize the lethality and various pharmacological activities of $N$. nigricollis venom. This activity might be corroborated with the diverse phytoconstituents revealed to be present in the plant materials. The plant could serve as therapy for patients with snakebite envenomation.

\section{References}

1. Cos P, Vlientinek AJ, Vanden-Berghe D, Maes L. Anti-infective potentials of natural product: How to develop a stronger in vitro proof of concept. J Ethnopharmacol 2006;106:290-303.

2. Clark AM. Natural products as a resource for new drugs. Pharm Res 1996;13:1133-41.

3. Soejarto DD, Farnsworth NR. Tropical rain forest: Potential source of new drugs prospect. Bio Med 1989;32:244-56.

4. Thomas SD. Leptadenia hastata: A review of its traditional uses and its pharmacological activity. Med Chem 2012;2:148-50.

5. Togola A, Austarheim I, Thesis A, Diallo D, Paulsen BS. Ethnopharmacological uses of Erythrina senegalensis: A comparison of three areas in Mali and a link between traditional knowledge and modern biological science. J Ethnobiol Ethnomed 2008;4:174-9.

6. Betti JL, Rost S, Yemef AA, Tarla FN. Contribution to the knowledge of nonwood forest products of the far north region of Cameroon: Medicinal plants sold in the Koussri market. J Ecol Natl Environ 2011;3:241-54.

7. Dambatta SH, Aliyu BS. A survey of major ethno medicinal plants of Kano North Western Nigeria, their knowledge and uses by traditional healers. Bayero J Pure Appl Sci 2011;4:28-34.

8. Gold BS, Richard CD, Robert AB. Bites of venomous snakes. N Engl J Med 2002;347:347-56.

9. Argiolas A, Pisano JJ. Facilitation of phospholipase $A_{2}$ activity by mastoparans, a new class of mast cell degranulating peptides from wasp venom. J Biol Chem 1983;258:13697-702.

10. Sumana S, Rituparna G. Preliminary screening of aqueous Alstonia scholaris Linn bark extract for antivenom activity in experimental animal model. IOSR J Dent Med Sci 2017;16:120-3.

11. Meenatchisundaram S, Prajish G, Parameswari T, Subbraj AM. Studies on antivenom activity of Andrographis paniculata and Aristolochia indica plant extracts against Echis carinatus venom. Intern J Toxicol 2008;6:1-7.

12. Maya DC, Vasantha B, Mary VL, Arthur U, Krishnan PR, Lissy K. An improved method for isolation of antiviper venom antibodies from chicken egg yolk. J Biochem Biophys Methods 2002;51:129-38.

13. Cannon R, Ruha AM, Kashani J. Acute hypersensitivity reactions associated with administration of crotalidue polyvalent immune Fab antivenom. Ann Emerg Med 2008;51:407-11.

14. Chippaux JP. Snake-bites: Appraisal of the global situation. Bull World Health Organ 1998;76:515-24.

15. Silva LG, Lee IS, Kingdom DA. Special problem with the extraction of plants. In: Cann RJ, editor. Natural Products Isolation. New Jessey, USA: Humana Press Inc.; 1998. p. 343-64.

16. Stalh E. Drug analysis by chromatography and microscopy. In: A Practical Supplement to Pharmacopoeias. $1^{\text {st }}$ ed. Ann Arbor, Michigan: Ann Arbor Science Publishers; 1973. p. 219-24.

17. Trease EA, Evans WC. Pharmacognosy. $11^{\text {th }}$ ed. London: Churchill Livingstone Harcourt Health Service; 1978. p. 60-75.

18. Sofowora A. Screening plants for bioactive agents. In: Medicinal Plants and Traditional Medicine in Africa. Ibadan: Spectrum Books Ltd.; 1982. p. 289.

19. Tan NH, Tan CS. Acidimetric assay of phospholipase A2 using egg yolk as substrate. Ann Biochem 1988;170:282-8.

20. Enenebeaku CK, Umerie SC, Nwankwo MU, Enenebeaku UE. Antisnake venom activities of the leaf extracts of Asystasia gangetica ( $L$ ) and Newbouldia leavis (p. Beauv). World News Natl Sci 2018;16:33-41.

21. Hasson SS, Al-Jabri AA, Sallam TA, Al-Balushi MS, Mothana RA. Antisnake venom activity of Hibiscus aethiopicus L. against Echis ocellatus and Naja N. nigricollis. J Toxicol 2010;2010:837864.

22. Ode OJ, Asuzu IU. The anti-snake venom activities of the methanolic extract of the bulb of Crinum jagus (Amaryllidaceae). Toxicon 2006;48:331-42.

23. Boche J, Chippaux JP, Courtois B. Contribution 'al'etude des variations biochimiques desvenins de serpents d'Afrique de I'Ouest. Bull Soc Pathol Exot Filiales 1981;74:356-66.

24. Broadle YD. A review of the African cobras of the genus Naja (Serpentes: Elapinae). Arnoldia 1968;3:1-14. 